\title{
Alternative Assessments in Online Learning during Covid-19 Pandemic: The Strenghths and Weaknesses
}

\section{Ahmad Arifuddin ${ }^{1}$, Turmudi2 ${ }^{2}$ Ummi Nur Rokhmah ${ }^{3}$}

1,3 Department of Madrasah Ibtidaiyah Teacher Education, IAIN Syekh Nurjati Cirebon, Indonesia

${ }^{2}$ Department of Mathematics Education, Universitas Pendidikan Indonesia, Indonesia

\section{A R T I C LE IN F O}

Article history:

Received March 19, 2021

Revised March 20, 2021

Accepted April 27, 2021

Available online May 25, 2021

\section{Kata Kunci:}

Penilaian, Pembelajaran Daring,

Pendidikan Dasar

Keywords:

Assessments, Online Learning, Elementary Education

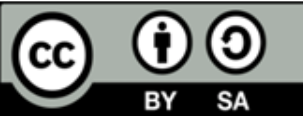

This is an open access article under the CC BY-SA license.

Copyright $(2021$ by Author. Published by Universitas Pendidikan Ganesha.

\begin{abstract}
A B S T R A K
Saat ini, pembelajaran online menjadi tren baru dalam dunia pendidikan Indonesia. Namun, para pendidik belum siap untuk beradaptasi dengan pembelajaran online, terutama dalam penilaian pembelajaran online. Penelitian ini bertujuan untuk mendeskripsikan alternatif penilaian dalam pembelajaran online yang dapat diterapkan di pendidikan dasar beserta kelebihan dan kekurangannya. Penelitian ini menggunakan pendekatan kualitatif dengan metode literature review. Peneliti mengumpulkan sejumlah artikel jurnal nasional dan internasional bereputasi, buku teks, buku pegangan, peraturan, dan sebagainya dari database google sarjana, science direct, eric, dan lain-lain yang terkait dengan masalah dan tujuan penelitian. Analisis tinjauan pustaka menggunakan metode penilaian kritis. Hasil penelitian ini menunjukkan bahwa penilaian pembelajaran online yang dapat diterapkan di pendidikan dasar adalah penilaian formatif dan sumatif. Ini termasuk penilaian kognitif, penilaian kinerja, portofolio, tulisan dan jurnal, penilaian diri dan penilaian rekan. Penggunaan penilaian pembelajaran online memiliki banyak keuntungan seperti ketersediaan untuk melakukan tes sesuai permintaan dan kapan saja, memberikan umpan balik langsung kepada pengguna, akses cepat siswa ke hasil tes, dan pengukuran pembelajaran siswa yang lebih akurat. Namun, sistem penilaian online juga memiliki beberapa kelemahan, seperti siswa yang memiliki keterampilan teknologi informasi (TI) yang rendah mungkin akan dirugikan. Untuk itu, dalam melaksanakan pembelajaran dan penilaian online, guru dan siswa harus menguasai keterampilan teknologi informasi dan komunikasi.
\end{abstract}

\section{A B S T R A C T}

Currently, online learning becomes a new trend in the Indonesian education. But, the educators are not ready to adapt to online learning, especially in online learning assessments. This study aims to describe the alternative assessments in online learning that can be implemented at elementary education along with its advantages and disadvantages. This study employed a qualitative approach with the literature review method. Researchers collected a number of reputable national and international journal articles, textbooks, handbooks, regulations, and so on from the google scholar database, science direct, eric, and others related to research problems and objectives. The analysis of the literature review uses the critical appraisal method. The results of this study showed that online learning assessments that can be implemented in elementary education were formative and summative assessments. It included cognitive assessments, performance assessments, portfolios, writings and journals, self-assessment and peers-assessments. The use of online learning assessments has many advantages such as the availability to conduct tests on demand and at any time, provides direct feedback to users, the students' quick access to the test results, and a more accurate measurement of student learning. However, online assessment systems also have several drawbacks, such as students who have low information technology (IT) skills might be disadvantaged. For this reason, in implementing online learning and assessment, teachers and students should master information and communication technology skills.

\section{INTRODUCTION}

Nowadays, online learning becomes a new trend in the Indonesian education. The booming of online learning in Indonesia is due to the coronavirus outbreak that hits this country. The concept of online learning has actually been piloted to Indonesian educators since 2009. However, many of them are not ready to adapt to the today's challenges, namely online learning (Asmuni, 2020; Sari, 2012). Online learning is doing learning via computers with its supporting resources (Carliner, 2004; Garbe et al., 2020). Meanwhile, online learning is an access to learning experiences using several technologies (De Mauro et al., 2018; Moore et al., 2011). In line with this, online learning is a learning model that uses the internet media via websites, so that the learning process is carried out virtually or without a face-to-face meeting between teachers and students (Abidah et al., 2020; Himawan, 2011). In this regard, online learning is the latest version of distance learning (A. Benson, 2002; Zainal, 2020). 
The results of several relevant previous studies revealed that there were many obstacles in the practical implementation of online learning. The results of a previous study revealed that educators and students experienced difficulties in teaching practices and communication patterns (Markova et al., 2017). Other research stated that online learning has led students be isolated and feel confused; it has also reduced their interest in learning the subject matter (Ni, 2013; Zaborova \& Markova, 2016). In addition, the results of a study revealed some obstacles that students faced when doing online learning such as the unavailability of technological devices (smartphones, computers or laptops) to support their learning process (Purwanto et al., 2020). Students are also not able to adapt to the online learning culture. Their mastery in using information and communication technology is still limited. In addition, teachers have also experienced problems during the implementation of online learning. Not all teachers are proficient in using internet technology or social media as a learning tool. Some senior teachers are not yet fully able to use devices or facilities to support online learning activities; they need assistance and training first.

However, online learning should be implemented at every level of education units in Indonesia during the Covid-19 pandemic, from elementary school (SD/MI), junior high school (SMP/MTs), high school (SMA, MA, and SMK) to the higher education level. It is because during the Covid-19 pandemic, Indonesian people were required to follow health protocols suggested by the government, namely social distancing, physical distancing, washing hands, and wearing masks. Therefore, the learning process must be conducted at home through online learning (Asmuni, 2020; Sadikin \& Hamidah, 2020). There are many advantages of using online learning. First, the learning process becomes more flexible so that students can learn at their own pace. Second, it facilitates the student-centered learning so that students are responsible for their own learning. And third, through implementing online learning, teaching materials can be accessed by students at anywhere and anytime (Graff, 2003; Khusniyah \& Hakim, 2019; Nurhayati et al., 2020). Therefore, in order to answer the problems that arise in online learning, especially in the aspects of online learning assessment, this study aims to describe the alternative of assessment that teachers can use to assess elementary school (SD/MI) students, especially in the online learning during the Covid-19 pandemic

\section{METHOD}

The research is qualitative research with literature review method (Nassaji, 2015; Sugiyono, 2018). In this study, researchers collected a number of reputable national and international journal articles, textbooks, handbooks, regulations, and so on from the google scholar database, science direct, eric, and others related to research problems and objectives. This technique is carried out with the aim of expressing various theories that are relevant to the problems being faced / researched, namely assessment in online learning in elementary schools as reference material in the discussion of research results. Furthermore, researchers used literature review data collection with a thematic structure, namely grouping and discussing reference sources according to the theme or topic. By grouping research themes or topics, researchers can indicate topics that are important and strengthen acumen in research. The collection of literature reviews is used in several stages, including searching for articles based on the topic outline, grouping articles based on relevance to the topic and years of research, then sorting the structure of the explanation and comparison of related data. After the articles are collected, the researcher then groups the articles that have been obtained based on the relevance of the assessment topics in online learning and their strengths and weaknesses. In addition to topics, researchers also categorized articles based on the year of research. The article that focuses on research in the last 10 years, but if there is still knowledge or discussion that has not changed, it will be expanded to an article with the last 20 years of research. From the number of searches, obtained 40 articles that are relevant and in accordance with the research topic. The forty articles are used in discussing and comparing research by topic based on topic relevance. Then the articles that have been grouped are analyzed regarding the relevance of the articles and research topics. Then the researchers compared if there were related journals. The addition of journal articles and other textbooks is to strengthen and increase the sharpness of the discussion of research results.

The analysis of the journal from the literature review uses the critical appraisal method. Critical appraisal is a journal analysis process that is used as a theoretical basis regarding the differences, similarities and deficiencies of the journals used. Journals are reviewed to select the measurement results journal that fits the topic. After that it is analyzed using the critical appraisal by including: the title and author of the journal, the year of publication, the measured variables, the results of the research study and the relationship with the research that the researcher is researching. More about this source textSource text required for additional translation information. 


\section{RESULT AND DISCUSSION}

\section{Result}

\section{Basic Concepts of Learning Assessment}

Assessment is an important aspect in the teaching and learning system (Benson, 2003). Assessment is a way to understand children to make decisions about them (Sattler, 2008). Assessment can also be interpreted as a process to garner information regarding the student learning outcomes. Assessment is a process of collecting data about the students' knowledge, abilities, and dispositions towards mathematics; it is a process of making evidence of the student achievement of various learning objectives. Assessment includes all activities carried out by teachers and students to get information to change the teaching and learning process (Vonderwell et al., 2007). The assessment of student learning outcomes at the primary and secondary education levels must comply to the following principles: a) valid, the assessment is based on data that reflects the measured ability; b) objective, the assessment is based on clear procedures and criteria, not influenced by the subjectivity of the assessor; c) fair, the assessment does not take sides to certain students because of special needs and differences in religious, ethnic, cultural, cultural, social and economic status and gender; d) integrated, the assessment by the teacher is an inseparable component of learning activities; e) open, the assessment procedures, assessment criteria, and basis for decision making can be recognized by interested parties; e) comprehensive and continuous, the assessment covers all aspects of competence using various appropriate assessment techniques to monitor the students' learning progress; f) systematic, the assessment is carried out in systematically through following the standard steps; g) based on criteria, the assessment is based on the determined competencies; and h) accountable, the assessment can be justified, both in terms of techniques, procedures, and results. Meanwhile, there are two principles of learning assessment: 1) assessment must be able to improve the student learning process; and 2) assessment is a valuable tool for making decisions in teaching (Van de Walle et al., 2013). According to several studies, the purpose of assessment in learning is to monitor student progress, make decisions in teaching, evaluate student achievement, evaluate learning programs, and improve teaching and learning programs (Corcoran et al., 2004; Stiggins \& Chappuis, 2005; Van de Walle et al., 2013).

\section{Assessments in Online Learning}

Assessment is an integral part of the learning process, both in conventional education and online learning (Ogange et al., 2018). Online assessment is an assessment that uses computers to send and analyze tests (Astini, 2020; Graff, 2003). There are various forms of assessment that can be used in online learning at the primary education level (SD/MI), including formative and summative assessment (Ogange et al., 2018; Vonderwell et al., 2007). Formative assessment is an assessment that is carried out at the end of the learning period, while summative assessment is an assessment carried out at the end of the learning process (or at the end of the semester) (Graff, 2003). Formative assessment is effective in improving learning at all levels of education (Black \& William, 1998). Formative assessment can provide opportunities for further learning and conceptual development through feedback, interpretation, and dialogue between teachers and students (Sadler, 2010). In an online learning, the implementation of formative and summative assessment requires an understanding of the features and tools of the electronic media (Perera-Diltz \& Moe, 2014).

Formative and summative assessments can be in the form of cognitive assessments, performance appraisals, portfolios, writing, and journals (Mateo \& Sangrà, 2017; Perera-Diltz \& Moe, 2014; Reeves, 2000). First, cognitive assessment. Cognitive assessment is an assessment that focuses on measuring the students' higher order thinking skills, attitudes, and communication skills (Merluzzi et al., 1986). One popular cognitive assessment approach is concept mapping. The strategy allows students to externalize the relationships between concepts and processes in a domain and to reveal the structure of their knowledge. In addition to concept mapping, cognitive assessment can be in the form of problem solving that can be integrated into a web-based learning environment (Reeves, 2000). Second, performance appraisal. Performance appraisal is an assessment that measures the students' ability through creating several products or engaging in several activities (Jonassen et al., 1997). Meanwhile, performance appraisal is an assessment that correlates to the actual problem-solving activities used in teaching. Performance appraisal focuses on the students' ability to apply knowledge, skills, and assessments in a realistic context (Van de Walle et al., 2013). The keys to performance appraisal are: 1) focusing on complex learning, 2) involving higher-order thinking and problem-solving skills, 3) stimulating a variety of active responses, 4) engaging challenging tasks that require multiple steps, and 5) requiring a strong commitment, time, and students' effort (Linn et al., 1991). Several forms of performance appraisal are online discussions, fieldwork, and presentations (Kearns, 2012). Performance appraisal can be measured 
using a rubric and performance indicators. Figure 1 shows the examples of performance appraisal rubrics (Van de Walle et al., 2013).

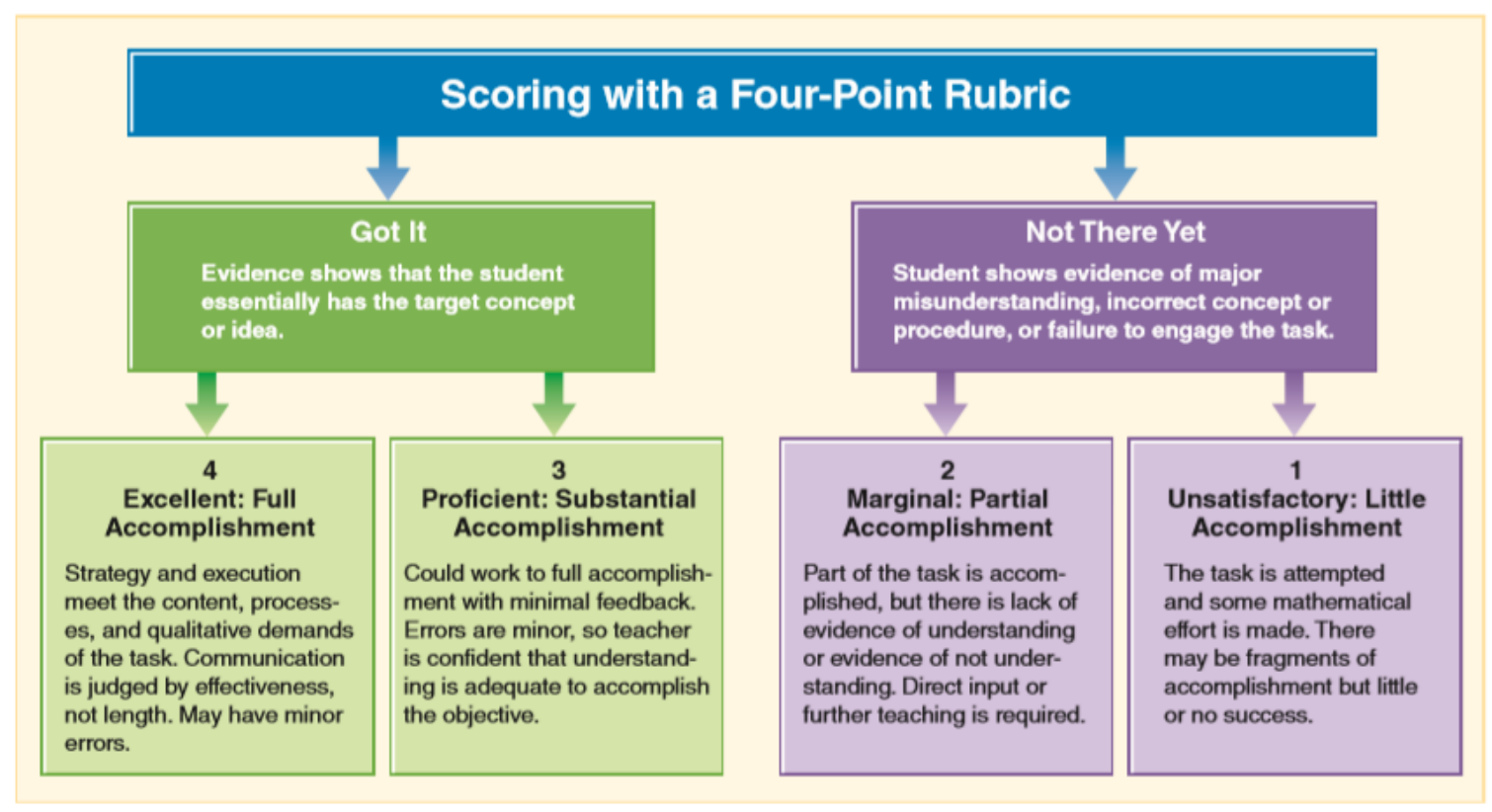

Figure 1. Examples of performance indicators for grades 3-4

Third, portfolio assessment. Portfolio assessment is an assessment that is used to document student works over time, so that the processes and products can be reviewed (Knight \& Gallaro, 1994). The portfolio assessment in this online learning assessment is an electronic portfolio. Regarding its advantages, a portfolio allows students to present their creations so that the teacher could get a better understanding of the student works holistically, not partial and unconnected from other aspects of their personality (Mateo \& Sangrà, 2017). Another advantage is that it is necessary to choose which products to include in the portfolio; students are required to decide consciously on the convenience of one or another part and that their capacity reflects the evolution of their most significant learning process. This will inevitably allow them to think at their level of knowledge and understanding of the intentionality of educational interventions on the one hand and the level of achievement on the other hand (Mateo \& Sangrà, 2017). From a digital point of view, technicians tend to understand portfolios as digital containers that are able to store text, images, sound, and even software instruments for managing large and diverse amounts of information (Abrami \& Barrett, 2005). However, from the perspective of the researcher, this is more than just creating a dynamic and comprehensive meeting room for teaching, evaluative, and student personal development (Barberà \& Ahumada, 2007). Fourth, writing and journal. Writing is an opportunity for learning and assessment. Some students at first have difficulty in writing about mathematics. As an assessment tool, writing provides a unique impression of students' perceptions and the way students think about an idea. Writing depicts the students' thinking, telling a lot to parents. Writing is more than test scores. When students write about their solutions to an assignment before online discussion, writing can serve as an exercise for conversations about work (Van de Walle et al., 2013).

Meanwhile, a journal is a way to make written communication a part of learning, especially in learning mathematics. The teacher feedback must be able to encourage the students' learning. A journal is an avenue for students to write about their mathematical experiences related to conceptual understanding and problem solving, descriptions of mathematical ideas, solutions and justification of problems, graphs, pictures and observations, questions about current topics, an idea that they may need help, or the area they do not quite understand, and their attitudes towards mathematics, their confidence in their understanding, or their fear of mistakes (Van de Walle et al., 2013). In addition to cognitive, performance, portfolio, writing and journal assessments, there are also self-assessments and peer assessments (Gaytan \& McEwen, 2007). The collaborative online peer learning process in education encourages critical reflection and self-assessment (Altınay, 2017). The ability and willingness to assess their own progress in learning is one aspect that students can develop (Stenmark, 1989). The power of mathematics is knowing how much we know and what to do to learn more. Student self-assessment is not the only measure of their learning or disposition, but a record of how they understand their strengths and 
weaknesses when they start to take on their responsibilities. In each case, self-assessment encourages students to become active learners. Although it takes time to incorporate this assessment into the daily schedule, it allows students to take part in the assessment. This process motivates students to monitor and adapt their approaches to learning. In its implementation, various types of assessment can be done using asynchronous web (not realtime). Asynchronous web can be used to integrate assessment activities that can help facilitate meaningful learning (Vonderwell et al., 2007). The asynchronous web media can be in the form of google classroom platform, personal website/blog, google form, email, and other social media such as Whats App, and so on.

\section{Strenghths and Weaknesses of Online Learning Assessments}

There are many advantages of using online assessment for students (Graff, 2003). For example, tests can be conducted at any time. Furthermore, online assessments use a computerized system that provides direct feedback to its users. Therefore, users learn by taking tests. Meanwhile, several benefits of using online assessment: (a) student grades can be immediately inputed into electronic classroom books, (b) students have faster access to results, (c) assessments provide a student-centered learning environment, and (d) it allows to measure learning more accurately (Bartlett et al., 2000). Online learning environments equipped with formative assessment tools provide three benefits to students (Zakrzewski \& Bull, 1998). First, it is flexible for students to take assessments at anytime and anywhere, as long as it is within the deadline. Second, students can make several assessment attempts until they achieve the desired minimum score. Third, online formative assessments provide students with the quick feedback and learning suggestions and correct weaknesses in their teaching and learning (Zakrzewski \& Bull, 1998). Furthermore, online formative assessments can help reduce the students' anxiety levels prior to summative assessment (Cassady \& Gridley, 2005). This is due to the asynchronous nature of the web in the online learning context; teachers can use formative assessment to increase interactivity between students and other students, and between students and teachers (Vonderwell et al., 2007).

In other words, effective online formative assessment can provide student-centered learning environments and increase student involvement so that their learning becomes more meaningful (Gikandi et al., 2011). In mixed learning, formative assessment has been shown to predict student learning outcomes (Klinkenberg, 2017). These important findings indicate that the use of formative assessment has the potential to motivate students and increase student interest in online learning and improve student learning outcomes. Then, in order for the implementation of online learning assessments to be effective, it is necessary to pay attention to the following online assessment techniques: (a) the development of realistic learning scenarios; (b) the alignment of learning objectives with realistic learning scenarios, (c) the use of software as soon as possible; (d) the availability of online mentors; and (e) the delivery of on-site instructor-based training that is responsive to individual learning differences (Boyle et al. 2003).

Since online assessments are an essential tool for effective learning, students and teachers must recognize the benefits of using online assessments. Online assessments provide a very useful training especially when being accessed repeatedly, and help reinforce classroom-based learning. They can also be used as a formal assessment in the module, if the questions are randomly selected from the pool. In addition, online assessments also provide direct feedback to students. Students can practice several times with similar questions, and at the same time students could get an immediate feedback. In this regard, the use of online assessment in learning is part of a critical constructivist teaching tool (Pezzino, 2018). However, there are several drawbacks when using online scoring systems. Students who have poor information technology (IT) skills may be disadvantaged in this online assessment (Graff, 2003). In addition, there is also a lack of student activities in online learning discussion (Soffer et al., 2017). These findings could provide insights that help improve the quality of assessments in the future online learning. In addition, there are several challenges in online assessments. The challenges of online assessment are due to the impact of physical distance between teachers and students, cultural adaptation in using technology to communicate with students, workload and time management issues, and ongoing need to collect various assessment data and provide feedback (Kearns, 2012).

\section{CONCLUSION}

Based on the of the results and discussion, it can be concluded that online learning assessment can be implemented at the elementary education level (SD/MI) wheter in the form of formative or summative assessments. The online assessments include cognitive assessments, performance assessments, portfolios, writing and journals, self-assessments and peers. In its implementation, various types of assessments can be applied using the asynchronous web, including the google classroom, 
personal website/blog, google form, email, and other social media platforms such as Whats App, and so on. The use of online assessments in online learning also has many advantages including the availability to conduct tests on demand and at any time, the use of a computerized system that provides direct feedback to users, the immediate input of student test scores in electronic class books, the students' faster access to the results of the tests, the provision of student-centered learning environments, and a more accurate measurement of learning. However, online assessment systems also have some disadvantages. Students who have low information technology (IT) skills might be disadvantaged. For this reason, in implementing online learning and assessment, teachers and students should master information and communication technology skills.

\section{REFERENCES}

Abidah, A., Hidaayatullaah, H. N., Simamora, R. M., Fehabutar, D., \& Mutakinati, L. (2020). The Impact of Covid-19 to Indonesian Education and Its Relation to the Philosophy of "Merdeka Belajar." Studies in Philosophy of Science and Education, 1(1), 38-49. https://doi.org/10.46627/sipose.v1i1.9.

Abrami, P., \& Barrett, H. (2005). Directions for research and development on electronic portfolios. Canadian Journal of Learning and Technology/La Revue Canadienne de l'apprentissage et de La Technologie, 31(3). https://www.learntechlib.org/p/43165/.

Altınay, Z. (2017). Evaluating peer learning and assessment in online collaborative learning environments. $\begin{array}{lllll}\text { Behaviour \& Information } \quad \text { Technology, } & 36(3),\end{array}$ https://doi.org/10.1080/0144929X.2016.1232752.

Asmuni, A. (2020). Problematika Pembelajaran Daring di Masa Pandemi Covid-19 dan Solusi Pemecahannya. Jurnal Paedagogy, 7(4), 281. https://doi.org/10.33394/jp.v7i4.2941.

Astini, N. K. S. (2020). Pemanfaatan Teknologi Informasi dalam Pembelajaran Tingkat Sekolah Dasar pada Masa Pandemi Covid-19. Lampuhyang, 13-25. https: //doi.org/10.47730/jurnallampuhyang.v11i2.194.

Barberà, E., \& Ahumada, M. E. (2007). Assessment of Research Competences Using e-Portfolio. eLearning.

Bartlett, J. E., Reynolds, K. A., \& Alexander, M. W. (2000). A tool for online learning. Journal of Online Learning, 11((3-4)), 22-24.

Benson, A. (2002). Using online learning to meet workforce demand: A case study of stakeholder influence. Quarterly Review of Distance Education, 3(4), 443-452. https: //www.learntechlib.org/p/95258/?nl=1.

Benson, A. D. (2003). Assessing participant learning in online environments. New Directions for Adult and Continuing Education, 100, 69-78. https://eric.ed.gov/?id=EJ772944.

Black, P., \& William, D. (1998). Inside the black box: Raising standards through classroom assessment. Phi Delta Kappan, 80(2), 139-148. https://doi.org/10.1177\%2F003172171009200119.

Carliner, S. (2004). An overview of online learning. Human Resource Development.

Cassady, J. C., \& Gridley, B. E. (2005). The effects of online formative and summative assessment on test anxiety and performance. The Journal of Technology, Learning and Assessment, 4(1). https://ejournals.bc.edu/index.php/jtla/article/view/1648.

Corcoran, C. A., Dershimer, E. L., \& Tichenor, M. S. (2004). A teacher's guide to alternative assessment: Taking the first steps. The Clearing House: A Journal of Educational Strategies, Issues and Ideas, 77(5), 213-218. https://doi.org/10.3200/TCHS.77.5.213-218.

De Mauro, A., Greco, M., Grimaldi, M., \& Ritala, P. (2018). Human resources for Big Data professions: A systematic classification of job roles and required skill sets. Information Processing and Management, 54(5), 807-817. https://doi.org/10.1016/j.ipm.2017.05.004.

Garbe, A., Ogurlu, U., Logan, N., \& Cook, P. (2020). Parents' experiences with remote education during COVID-19 school closures. American Journal of Qualitative Research, 4(3), 45-65. https://doi.org/10.29333/ajqr/8471.

Gaytan, J., \& McEwen, B. C. (2007). Effective online instructional and assessment strategies. The American Journal of Distance Education, 21(3), 117-132. https://doi.org/10.1080/08923640701341653.

Gikandi, J. W., Morrow, D., \& Davis, N. E. (2011). Online formative assessment in higher education: A review of the literature. Computers \& Education, 57(4), 2333-2351. https://doi.org/10.1016/j.compedu.2011.06.004.

Graff, M. (2003). Cognitive style and attitudes towards using online learning and assessment methods. Electronic Journal of E-Learning, 1(1), 21-28. https://www.academicpublishing.org/index.php/ejel/article/view/1810.

Himawan, H. (2011). Analisa dan Perancangan Sistem Pembelajaran Online Menggunakan Metode Parsing. Telematika: Jurnal Informatika Dan Teknologi Informasi, $7(2)$. 
http://jurnal.upnyk.ac.id/index.php/telematika/article/view/421.

Jonassen, D. H., Reeves, T. C., Hong, N., Harvey, D., \& Peters, K. (1997). Concept mapping as cognitive learning and assessment tools. Journal of Interactive Learning Research, 8(3), 289. https://www.proquest.com/openview/2443d7abc0dd854f0fcd3ac441ac7992.

Kearns, L. R. (2012). Student assessment in online learning: Challenges and effective practices. Journal of Online Learning and Teaching, 8(3), 198. http://jolt.merlot.org/vol8no3/kearns_0912.pdf.

Khusniyah, N., \& Hakim, L. (2019). Efektivitas Pembelajaran Berbasis Daring: Sebuah Bukti Pada Pembelajaran Bahasa Inggris. Jurnal Tatsqif, 17(1), 19-33. https://doi.org/10.20414/jtq.v17i1.667.

Klinkenberg, S. (2017). The Role of Formative Assessment in a Blended Learning Course. International Computer Assisted Assessment Conference, 63-71. https://doi.org/10.1007/978-3-319-57744-9_6.

Knight, M. E., \& Gallaro, D. (1994). Portfolio assessment: Applications of portfolio analysis. Univ Pr of Amer.

Linn, R. L., Baker, E. L., \& Dunbar, S. B. (1991). Complex, performance-based assessment: Expectations and validation criteria. Educational Researcher, 20(8), 15-21. https://doi.org/10.3102\%2F0013189X020008015.

Markova, T., Glazkova, I., \& Zaborova, E. (2017). Quality issues of online distance learning. Procedia-Social and Behavioral Sciences, 237, 685-691. https://doi.org/10.1016/j.sbspro.2017.02.043.

Mateo, J., \& Sangrà, A. (2017). Designing online learning assessment through alternative approaches: facing the concerns. European Journal of Open, Distance and E-Learning, 10(2). https://old.eurodl.org/?p=archives\&sp=full\&year=2007\&halfyear=i\&abstract=294.

Merluzzi, T. V., Glass, C. R., \& M., G. (1986). Cognitive Assessment. University Press.

Moore, J. L., Dickson-Deane, C., \& Galyen, K. (2011). (2011). e-Learning, online learning, and distance learning environments: Are they the same? The Internet and Higher Education, 14(2), 129-135. https://doi.org/10.1016/j.iheduc.2010.10.001.

Nassaji, H. (2015). Qualitative and descriptive research: Data type versus data analysis. Language Teaching Research, 19(2), 129-132. https://doi.org/10.1177/1362168815572747.

$\mathrm{Ni}$, A. Y. (2013). Comparing the effectiveness of classroom and online learning: Teaching research methods. Journal of Public Affairs Education, 19(2), 199-215. https://doi.org/10.1080/15236803.2013.12001730.

Nurhayati, S., Wicaksono, M. F., Lubis, R., Rahmatya, M. D., \& Hidayat, H. (2020). Peningkatan Kemampuan Guru Dalam Pembelajaran Daring Dengan Memanfaatkan Teknologi Informasi Bagi Guru SMA Negeri 5 Cimahi Bandung. Indonesian Community Service and Empowerment (IComSE), 1(2), 7076. https://doi.org/10.34010/icomse.v1i2.3878.

Ogange, B., Agak, J., Okelo, K., \& Kiprotich, P. (2018). Student perceptions of the effectiveness of formative assessment in an online learning environment. Open Praxis, 10(1), 29-39. https://search.informit.org/doi/10.3316/informit.42366925850441.

Perera-Diltz, D. M., \& Moe, J. L. (2014). Formative and summative assessment in online edu cation. Journal of Research in Innovative Teaching, 7(1). https://digitalcommons.odu.edu/chs_pubs/37/.

Pezzino, M. (2018). Online assessment, adaptive feedback and the importance of visual learning for students. The advantages, with a few caveats, of using MapleTA. International Review of Economics Education, 28, 11-28. https://doi.org/10.1016/j.iree.2018.03.002.

Purwanto, A., Pramono, R., Asbari, M., Hyun, C., Wijayanti, L., \& Putri, R. (2020). Studi Eksploratif Dampak Pandemi COVID-19 Terhadap Proses Pembelajaran Online di Sekolah Dasar. EduPsyCouns: Journal of Education, Psychology and Counseling, 2(1), 1-12. https://ummaspul.ejournal.id/Edupsycouns/article/view/397.

Reeves, T. C. (2000). Alternative assessment approaches for online learning environments in higher education. Journal of Educational Computing Research, 23(1), 101-111. https://doi.org/10.2190\%2FGYMQ-78FA-WMTX-J06C.

Sadikin, A., \& Hamidah, A. (2020). Pembelajaran Daring di Tengah Wabah Covid-19. Biodik, 6(2), 109-119. https://doi.org/10.22437/bio.v6i2.9759.

Sadler, D. R. (2010). Beyond feedback: Developing student capability in complex appraisal. Assessment \& Evaluation in Higher Education, 35(5), 535-550. https://doi.org/10.1080/02602930903541015.

Sari, E. R. (2012). Online learning community: a case study of teacher professional development in Indonesia. Intercultural Education, 23(1), 63-72. https://doi.org/DOI: $10.1080 / 14675986.2012 .664755$.

Sattler, J. M. (2008). Resource guide to accompany assessment of children: Cognitive foundations. JM Sattler.

Soffer, T., Kahan, T., \& Livne, E. (2017). E-assessment of online academic courses via students' activities and perceptions. Studies in Educational Evaluation, 54, 83-93. https://doi.org/10.1016/j.stueduc.2016.10.001. 
Stenmark, J. K. (1989). Assessment alternatives in mathematics: An overview of assessment techniques that promote learning. Equals Publications.

Stiggins, R., \& Chappuis, J. (2005). Using student-involved classroom assessment to close achievement gaps. Theory into Practice, 44(1), 11-18. https://doi.org/10.1207/s15430421tip4401_3.

Sugiyono. (2018). Metode Peneiltian Kuantitatif, Kualitatif dan R\&D. Alfabeta Bandung.

Van de Walle, J. A., Karp, K. S., \& Bay-Williams, J. M. (2013). Elementary and middle school mathematics: Teaching developmentally. Pearson Education, Inc.

Vonderwell, S., Liang, X., \& Alderman, K. (2007). Asynchronous discussions and assessment in online learning. Journal of Research on Technology in Education, 39(3), 309-328. https://doi.org/10.1080/15391523.2007.10782485.

Zaborova, E. N., \& Markova, T. L. (2016, February). Students as social actors of virtual educational environment. In Actual Issues of Sociology of Culture, Education, Youth and Management: Materials of the All-Russian Scientific Conference with international participation (pp. 392-397).

Zainal, N. H. (2020). Tantangan Kebijakan Pembelajaran Jarak Jauh Di Era Pandemi COVID 19. Jurnal Pencerahan, 14(2), 133-151. http://www.jurnalpencerahan.org/index.php/jp/article/view/31.

Zakrzewski, S., \& Bull, J. (1998). The mass implementation and evaluation of computer-based assessments. Assessment \& Evaluation in Higher Education, 23(2), 141-152. https://doi.org/10.1080/0260293980230203. 